\title{
The Distribution of Metals in Sediments of the Likova, Kumanova and Pçinja Rivers: Spring Season
}

\author{
Nazmi Ejupi', Bardha Korça², Bujar H. Durmishi ${ }^{*}$, Arbana Durmishi' ${ }^{1}$ Egzona Ejupi ${ }^{1}$, \\ Murtezan Ismaili', Ahmed Jashari' ${ }^{1}$, Agim Shabani' \\ 1 University of Tetova, Faculty of Mathematics and Natural Sciences, Department of Chemistry, Str. llindeni n.n., \\ 1200 Tetova, Republic of Macedonia \\ 2 University of Prishtina, Faculty of Mathematics and Natural Sciences, Str. „Nëna Terezë” n.n., 10000 Prishtina, \\ Republic of Kosova \\ * Corresponding author's e-mail: bujar.durmishi@unite.edu.mk
}

\begin{abstract}
The pollution of rivers is an important issue because the utilization of polluted water has a direct effect on the health of people and other living beings, economy, etc. Sediments represent a very suitable indicator for monitoring and detecting pollution sources of river waters. The aim of this study is to analyze the contents of selected metals in the sediments of the rivers Likova, Kumanova and Pçinja rivers. The water samples were taken in June 2014 from six sampling stations. Several physicochemical parameters of rivers were determined and the contents of twenty-two metals was indicated in the sediment samples taken from these rivers. The obtained physico-chemical quality of the water from these rivers resulted in classification to the first/second category. The sediments were mostly polluted by Al, $\mathrm{Ca}, \mathrm{Na}$ and $\mathrm{Mg}$. The metals that exceeded the Dutch standard were: $\mathrm{Ba}, \mathrm{Ni}, \mathrm{Zn}, \mathrm{Cr}$ and $\mathrm{Cu}$. The order of metals in sediments was as follows: $\mathrm{Fe}>\mathrm{Al}>\mathrm{Ca}>\mathrm{Na}>\mathrm{Mg}>\mathrm{K}>\mathrm{Mn}>\mathrm{Ba}>\mathrm{Sr}>\mathrm{Cr}>\mathrm{Zn}>\mathrm{V}>\mathrm{Ni}>\mathrm{Cu}>$ $\mathrm{Pb}>\mathrm{Li}$. The study results reveal a mild pollution in rivers caused by urban, agricultural and industrial activities.
\end{abstract}

Keywords: metals, pollution, physical-chemical parameters, sediments, river water

\section{INTRODUCTION}

Water is the main source of life on earth. Surface waters are crucial for the lives of people, animals, water flora and fauna, industry, sports, etc. Today, the quality of water in rivers is deteriorating and pollution represents a serious threat in the developing countries. The pollution of rivers and the sediments in them occurs everywhere in the world because of the rapid increase in the population, urbanization, industry and intensive agricultural practices. In this context, the identification of main anthropogenic pollution sources and the assessment of their impact on the lower ecological and socio-economic flow represents an essential challenge to the management of water resources. Industrial development has caused an increase in the amount of chemical matter used in the industry as raw materials [Shanur, 2015]. As a result, an increased emission of heavy metals in waters and sediments of the rivers can be noticed. Industrial wastes have a negative influence on water habitats and pollution is caused by their direct and/or indirect toxic activity, thus changing the quality of the water.

Heavy metals, including essential and nonessential elements play an important role in ecotoxicology, because they are toxic to living organisms. The bioaccumulation and bio-expansion of these metals in fish and other creatures at toxic levels is possible even when their exposure is low; on the other hand, trace elements have expanded their influence on the environment due to their usage in people's everyday lives [Mandalia, 2011]. The main natural processes that contribute to the presence of trace elements in waters are chemical erosion of rocks and soil drainage. Recently, anthropogenic activities have caused an increase in 
the amount of heavy metals in water ecosystems and the pollution of these systems with heavy metals has reached alarming levels, thus becoming a serious global problem [Malik, 2010].

Heavy metals cannot retain a soluble form in water for a long time. They usually form colloids in an abeyant state or become merged with organic and inorganic substances. Thus, their concentration in sediments or planktons increases and often the sediment is a very suitable indicator of water pollution with heavy metals. Sediments can be considered as a final "sink" for trace metals, which are discharged in the water habitat [Dossis and Warren, 1980].

Unlike organic polluters, heavy metals do not undergo natural decomposition and as such they infiltrate into natural waters and become part of the water sediments. The processes of their distribution are controlled by a dynamic group of physical and chemical interactions and equilibriums [Jain, 2004]. In this way, the pollution of rivers with heavy metals deteriorates the delicate equilibrium of water systems. Unlike organic pollutants, heavy metals are peculiar for their long half-life and their negative effects on water organisms are long-lasting. Heavy metals are serious pollutants of the environment, and the determination of heavy metal concentrations in various different habitats reveals their pollution level [Bekteshi, 2014].

Sediments behave as an important source of metals in water habitats and represent a "time bomb" for the future pollution of the whole ecosystem. As a consequence of the change of conditions in the sediment/water system, the physicochemical parameters also change $(\mathrm{pH}$ value, redox potential, the content of organic matter, sulphides, etc.) and because of that it may lead to the process of the desorption of the metal from the sediment, mobility, transportation in a watery phase, and the manifestation of harmful effects in the eco-system. The contaminated sediment can cause serious economic problems, apart from negative ecological consequences.

Heavy metals in water ecosystems and in sediments have a natural and anthropogenic origin; the distribution and accumulation of metals is influenced by the texture of the sediment, its mineralogical composition, oxide-reductive state, absorption-desorption processes and physical transportation [Mollazadeh, 2013].

The anthropogenic sources of pollution mainly include various different industrial branches and intensive agricultural practices, as well as urban pollution. That is why the pollution of the environment with metals is considered a huge concern - the toxicity of heavy metals in different habitats has been reported by many authors. In recent years, there have been extraordinary attempts to characterize the fate, weight and distribution of heavy metals in sediments, especially in big rivers [Sakan, 2009]. In many papers, it is reported that dumping inorganic and organic pollutants at trace levels have constantly polluted the water in rivers and the sediments in them; therefore, one of the important results of the stability of heavy metals is the expansion of metals in the food chain [Rahimi, 2012; Mehdi Hosseini, 2012]. The pollution of sediments with heavy metals in many European rivers has been a study focus of numerous researchers and scientists; many such studies have focused on the industrialized parts of Europe [Oetken, 2005]. Some studies have shown that water sediments have been polluted with heavy metals in these industrialized areas. Therefore, the assessment of the distribution of metals in sediments is useful to understand the pollution level in water systems [Gehan, 2012]. Even though studies have been conducted in this field, it is still at its initial stage and, therefore, it is necessary for the studies to adapt to the local needs and possibilities.

The research on the concentration of heavy metals in river sediments in Macedonia has not been that frequent and in most of the rivers, it is still unknown. The aim of this paper was to examine the composition of some metals in the sediments of Likova, Kumanova and Pçinja rivers, in order to assess the suitability of their water for general usage purposes. Metals, as pollutants, have been purposefully selected, because their concentrations can cause serious toxic effects in the surrounding industrialized and urbanized environment.

\section{MATERIALS AND METHODS}

\section{The study area}

The Likova, Kumanova, and Pçinja rivers, located in the region of the city of Kumanovo, Republic of Macedonia, were chosen for purposes of this study because lately there have been indications that they had been affected by the urban, agricultural and industrial pollution (Figure 1). The 
Likova River is in the northwestern part of Macedonia and is a tributary of the Kumanova River. The source of this river is located in the village of Goshince with the conjunction of the Goshince river and Breshtani river, whereas the Slupçane river serves as its left tributary. In the upper flow, it has a mountainous character, whereas in the lower flow up to the spill, it has a field character. This river is $17.5 \mathrm{~km}$ long, whereas its basin covers an area of $300 \mathrm{~km}^{2}$. Two artificial lakes have been created in this basin - the artificial lake of Likova and Glazhnja. The average flow of this river is $1.42 \mathrm{~m}^{3} / \mathrm{s}$. The Kumanova River is situated in the northeastern part of Macedonia and flows out east to the Skopska Crna Gora. It flows through the city of Kumanova and ends as a right tributary of Pçinja River. It is $44 \mathrm{~km}$ long with an overall fall of $1060 \mathrm{~m}$. Its basin covers an area of $460 \mathrm{~km}^{2}$. The Likova River is its most important tributary. The basin of this river is bare and, there- fore, its bed is porous, causing frequent floods. The Pçinja River is the left tributary of the Vardar River. This river belongs to the Aegean basin and it covers an area of $3140 \mathrm{~km}^{2}\left(1247 \mathrm{~km}^{2}\right.$ in Serbia and $1893 \mathrm{~km}^{2}$ in Macedonia). Other left tributaries include the Bistrica, Petroshnica and Kriva Reka rivers, whereas the Kumanova River is its right tributary.

\section{Acquisition of samples and their preparation}

In order to achieve the research objectives, samples for the phisico-chemical analysis of the water and sediments were obtained on 01.06.2014 from six sampling stations: L1, L2, L3, K1, P1 and $\mathrm{P} 2$. Three of these stations are situated along the flow of the Likova River (L1, L2, and L3), one is situated along the flow of the Kumanova River (K1) and two along the flow of the Pçinja River (P1 and P2) (Figure 1). The L1 station was

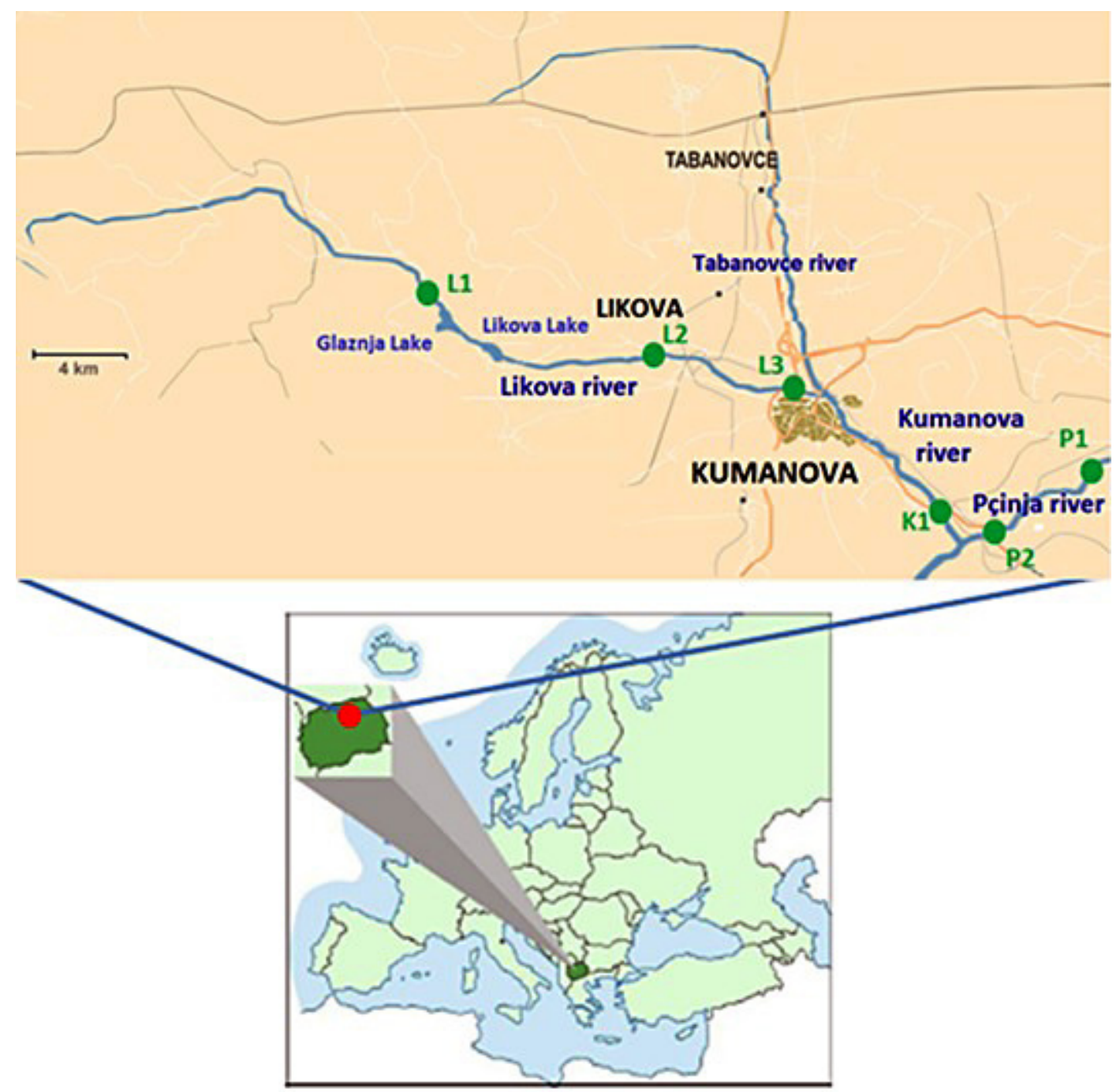

Figure 1. Map of monitoring stations 
before the Glazhnja accumulation, the L2 station was after the Likova accumulation, the L3 station was at the exit of the village of Likova before the city of Kumanova; the K1 station was outside the city of Kumanova and the plant for urban wastewater treatment ahead of the debouchments in the Pçinja River. The P1 and P2 stations are situated before the conjunction of rivers Kumanova and Pçinja. The selection of stations was based on the probable pollution indicators.

The water samples were taken using clean and sterilized polyethylene bottles with the volume of 1L. All of these bottles were submerged in $10 \%$ nitric acid for a night and then were rinsed out several times with ultrapure water before sampling took place. Prior to being filled, the bottles were washed with the river water three times and then were filled with flowing river water along the river flow. The sample bottles were labeled with the name of the respective station as well as the filling time and date. The sediment samples from the river beds were taken in accordance with the methods used for shallow rivers [Lewis and McConchie, 1994]. These methods include the usage of respective sampling equipment under water at a depth of $10 \mathrm{~cm}$ to $20 \mathrm{~cm}$. Two subsamples were taken at every station, which were then combined into one single sample, and then placed in the polyethylene bottles.

\section{Treatment and analysis of waters}

The physico-chemical parameters of the water in the mentioned rivers were analyzed at the Public Healthcare Center in Kumanova. Each water sample was analyzed for nine parameters: color, turbidity, $\mathrm{pH}$, electrolytic conductivity (EC), chemical oxygen demand (COD), ammonia, nitrites, nitrates, and chlorides. In the laboratory, water samples were filtered through the Whatman membrane filter, with $0.45 \mu \mathrm{m}$ pore diameter. The above-mentioned parameters were determined by referring to the standardized methods, as cited in the literature review [APHA, AWWA, WEF, 1995]. The color was determined colorimetrically using a comparator; the $\mathrm{pH}$ value was measured using a pH-meter; EC was measured using conductometer; COD was measured using the $\mathrm{H}_{2} \mathrm{SO}_{4}$ and $\mathrm{H}_{2} \mathrm{C}_{2} \mathrm{O}_{4}$ method; ammonia, nitrites, and nitrates were measured with a UV-Vis spectrophotometer and chlorides were measured with a argentometric titration.

\section{Treatment and analysis of sediments}

The metals in sediments were analyzed at the Chemistry Institute laboratories in the city of Skopje. The sediment samples were characterized by the composition of the following metals: $\mathrm{Ag}, \mathrm{Al}, \mathrm{As}, \mathrm{Ba}, \mathrm{Ca}, \mathrm{Cd}, \mathrm{Co}, \mathrm{Cr}, \mathrm{Cu}, \mathrm{Fe}$, $\mathrm{K}, \mathrm{Li}, \mathrm{Mg}, \mathrm{Mn}, \mathrm{Mo}, \mathrm{Na}, \mathrm{Ni}, \mathrm{Pb}, \mathrm{Sr}, \mathrm{Tl}, \mathrm{V}$ and $\mathrm{Zn}$. The analyses were carried out by using standard analytical methods. The samples were initially taken to laboratories where they were dried in fully aired rooms for the period of 8 to 10 days. Afterwards, they underwent a sieving process; $0.2528 \mathrm{~g}$ of the sieved sediment was measured from every sediment and $5 \mathrm{~mL}$ of $\mathrm{HNO}_{3} 65 \%$ solution was added to it. This composition was heated until only $1 \mathrm{~mL}$ of the sample solution remained. The obtained solution was then cooled for 5 to 10 minutes; $5 \mathrm{~mL}$ of $\mathrm{HF} 40 \%$ solution and $1.5 \mathrm{~mL}$ of $\mathrm{HClO}_{4} 60 \%$ solution were added to the newly formed solution and it was heated again until another $1 \mathrm{~mL}$ of the sample solution remained. Afterwards, 2 $\mathrm{mL}$ of $\mathrm{HCl} 37 \%$ and $5 \mathrm{~mL}$ distilled water were added to the latter and it was cooled for 1 to 2 minutes; it was subsequently filtered using a plastic funnel. The obtained filtrate was put in a normal plastic flask with the volume of 5 $\mathrm{mL}$. This is how the sample was prepared for a spectrometric measurement.

\section{Instrumentation}

Twenty two metals in the sediments from the selected rivers were examined. Metals such as $\mathrm{Ca}, \mathrm{Fe}, \mathrm{K}, \mathrm{Mg}$, and $\mathrm{Na}$ were analyzed with the Varian ICP-AES $715 \mathrm{~S}$ atomic emission spectrometer, in the inductively coupled plasma atomic emission spectrometry process, whereas other remaining metals were analyzed with inductively coupled plasma mass spectrometry (ICP-MS).

\section{Quality control}

The quality control of the applied techniques was performed by standard addition method. The obtained recovery for the analysed elements for ICP-AES ranged between $98.0 \%$ and $101.5 \%$. The same method was applied for the determination of certain trace elements in the reference standard materials JSAC 0401 (soil) and SARM 3 (rock), yielding values very close to those certified. 


\section{RESULTS AND DISCUSSION}

The results of physico-chemical analyses of the water from the Likova, Kumanova and Pçinja rivers are shown in Table 1, whereas the results of the analyses of metals in sediments in Tables 2-4, and Figures 2-4.

\section{Physico-chemical parameters of the water in rivers}

\section{The color}

The color of the water is an organoleptic parameter of the water, which provides a preliminary assessment of pollution. The notion of "the color of the water" refers to its nuance that is produced by the presence of metal ions, humus compositions and particles suspended from pollutants. The results from the analysis of this parameter show that the water in the selected rivers was of relatively high quality because the color of the water could not be detected in any of the sampling stations (Table 1).

$p H$

The $\mathrm{pH}$ is classified as secondary tap water pollutant, the impact of which is considered as aesthetic [Durmishi, 2013]. The high or a low $\mathrm{pH}$ value shows the alkaline or acidic conditions of the water, respectively. The $\mathrm{pH}$ value is affected by the geology and types of soil, by natural organic acids present in water, as well as by the acidic rain, which usually has a $\mathrm{pH}$ value between 3.5 and 5.5. The $\mathrm{pH}$ values in the season of spring ranged between 7.40 and 7.88; they varied within the allowed limits and do not represent pollution of river waters. The average seasonal value with standard deviation was $7.67 \pm 0.21$. The low- est value of 7.40 was measured at the $\mathrm{K} 1$ station. This value is thought to be a consequence of the accidental penetration of acidic substances in the Kumanova River. The highest value of 7.88 was measured at P2 station and it could refer to the pollution caused by the wastewaters flowing from the city of Kumanova and other surrounding areas. The $\mathrm{pH}$ values had a decreasing trend from $\mathrm{L} 1$ to $\mathrm{K} 1$ and then an increasing trend from $\mathrm{K} 1$ to $\mathrm{P} 2$.

\section{Electrolytic conductivity}

Electrolytic conductivity (EC) is the measure of the ability of a material to accommodate the transport of an electric current and it largely depends on the amount of salts dissolved in water. $\mathrm{EC}$ is an important measure of the water quality, because it gives very concrete information about the amount of dissolved materials in the water. EC can also help to find potential pollution sources, because the polluted water usually has higher values compared to the clean water. EC values quite often show the pollution from road salts, septic systems, waste water management plants, or urban/agricultural drainages. High EC values show pollution of the water in rivers. The $\mathrm{PE}$ values ranged from 248.00 to $470.00 \mu \mathrm{S} / \mathrm{cm}$, being within the range of recommended values, i.e. indicating low pollution. The average seasonal value with standard deviation was $315.17 \pm 82.77$ $\mu \mathrm{S} / \mathrm{cm}$. The highest value was measured at $\mathrm{K} 1$ station, whereas the lowest was measured at L2. $\mathrm{PE}$ had an increasing trend from L1 to K1, a decreasing trend from K1 to P2 and then a slightly increasing trend from $\mathrm{P} 1$ to $\mathrm{P} 2$.

\section{Turbidity}

Turbidity is a measure of the amount of material suspended in water. It constitutes the cloudiness or haziness of a fluid caused by large num-

Table 1. Results of physico-chemical analyses of the water from the Likova, Kumanova and Pçinja rivers

\begin{tabular}{|l|c|c|c|c|c|c|c|c|}
\hline $\begin{array}{c}\text { Phisico-chemial } \\
\text { parameters }\end{array}$ & Unit & L1 & L2 & L3 & K1 & P1 & P2 & $\begin{array}{c}\text { Maximal } \\
\text { values }\end{array}$ \\
\hline Color & ${ }^{\circ} \mathrm{Pt}-\mathrm{Co}$ & $\mathrm{nd}^{*}$ & $\mathrm{nd}$ & $\mathrm{nd}$ & $\mathrm{nd}$ & $\mathrm{nd}$ & $\mathrm{nd}$ & 20 \\
\hline Turbidity & $\mathrm{NTU}$ & 0.558 & 0.352 & 0.365 & 0.485 & 1.2 & 1.35 & 4 \\
\hline $\mathrm{pH}$ & $/$ & 7.85 & 7.58 & 7.48 & 7.4 & 7.82 & 7.88 & $6.8-8.5$ \\
\hline $\mathrm{EC}$ & $\mathrm{\mu S} / \mathrm{cm}$ & 255 & 248 & 340 & 470 & 280 & 298 & 1000 \\
\hline $\mathrm{COD}$ & $\mathrm{mg} / \mathrm{L}$ & 1.7 & 1.65 & 0.8 & 0.81 & 1.51 & 1.18 & 5 \\
\hline Ammonia & $\mathrm{mg} / \mathrm{L}$ & $\mathrm{nd}$ & $\mathrm{nd}$ & $\mathrm{nd}$ & $\mathrm{nd}$ & $\mathrm{nd}$ & $\mathrm{nd}$ & 0.50 \\
\hline Nitrites & $\mathrm{mg} / \mathrm{L}$ & $\mathrm{nd}$ & 0.0115 & 0.0136 & $\mathrm{nd}$ & $\mathrm{nd}$ & $\mathrm{nd}$ & 0.10 \\
\hline Nitrates & $\mathrm{mg} / \mathrm{L}$ & 0.351 & 0.453 & 1.527 & 2.508 & 0.568 & 0.567 & 50 \\
\hline Chlorides & $\mathrm{mg} / \mathrm{L}$ & 2.55 & 2.55 & 3.58 & 13 & 5.52 & 6.83 & 250 \\
\hline
\end{tabular}

*nd - not detected 
bers of individual particles that are generally invisible to the naked eye, similar to smoke in air. The measurement of turbidity is a key test of water quality. This material, comprising of particles from clay, mud, algae, floating sediments and rotten plant substances, causes distribution and absorption of light, increase water temperature and decrease the dissolved oxygen concentration. High turbidity can also lower the amount of light that can penetrate water, which in turn reduces the process of photosynthesis and the production of dissolved oxygen. Clean waters have low turbidity in general. Rainfalls increase the turbidity in surface waters by washing the sediments, organic matters and other substances away. Human activity, such as destruction of vegetation and soil can lead to a dramatic increase in the turbidity levels. The measured turbidity in all of the samples was less than 1.5 nephelometric units (NTU). The results of the turbidity analysis have been shown in Table 1 and they are within the recommended values, ranging from 0.352 to 1.350 NTU units. The average seasonal value with a standard deviation was $0.718 \pm 0.441 \mathrm{NTU}$. The highest value was measured at P2 and the lowest at L2.

\section{Chemical Oxygen Demand}

Chemical Oxygen Demand (COD) is a measurement of the oxygen required to oxidize soluble and particulate organic matter in water. COD is used to determine the amount of organic pollutants in surface waters and wastewaters, making it a useful measurement tool for the quality of the water. COD is the amount of oxygen that is needed to oxidize the organic pollution by using strong oxidizing agents. The water samples in spring had the COD values ranging from 0.80 to $1.70 \mathrm{mg} / \mathrm{L}$ (Table 1). The average seasonal value with a standard deviation was $1.28 \pm 0.41 \mathrm{mg} / \mathrm{L}$. The lowest COD value was measured at L3, whereas the highest was obtained at L1, which can be related to some accidental pollution by organic pollutants, since pollution at the upper flow of rivers is usually lower than that at the lower flow. COD marked a decreasing trend form L1 to $\mathrm{K} 1$, then an increasing trend from $\mathrm{K} 1$ to $\mathrm{P} 1$ and another decreasing trend from P1 to P2. The results show that river waters are not polluted by organic substances.

\section{Ammonia, nitrites and nitrates}

The presence of substances that are created from the decomposition of wastes of animal ori- gin is of crucial importance in terms of assessing the quality of surface waters. The waters containing products from this decomposition are usually microbiologically polluted. In polluted waters, different products can be created, such as compositions of $\mathrm{C}$ and $\mathrm{S}$, as well as those of $\mathrm{N}$, which are of particular importance. Nitrogen in these products appears in the form of ammonia, nitrites, and nitrates, coming from effluent waters from industries and households. These parameters are the most usual indicators for the assessment of the quality of water in rivers. The concentration levels of nitrites and nitrates and the ammonia, expressed in $\mathrm{mg} / \mathrm{L}$ have been given in Table 1.

The presence of ammonia in water is a very dangerous occurrence. The permissible amount of ammonia in surface waters, according to the regulations in Macedonia, cannot exceed $0.5 \mathrm{mg} / \mathrm{L}$. Fortunately, we could not detect the presence of this substance in any of the examined stations. Nitrites are also toxic and their amount in water is maximally limited to $0.1 \mathrm{mg} / \mathrm{L}$. They are created in the water from the dissolution of biological and industrial pollutants. The contents of nitrites in L2 and L3 stations was 0.0115 and 0.0136 respectively, whereas in other sampling stations it could not be detected at all. Nitrates represent a higher degree of oxidation in the circulation of nitrogen in nature. High levels of nitrates are not desirable, because they can be reduced to nitrites under the influence of the red flora, and nitrites are toxic, as mentioned earlier. Nitrates represent the final product of the biological oxidation of organic pollutants. This shows that the water had been polluted earlier.

The range of nitrates for the season of spring in stations was $0.351-2.508 \mathrm{mg} / \mathrm{L}$, which is within the normal values. The average seasonal value with standard deviation was $0.996 \pm 0.854 \mathrm{mg} / \mathrm{L}$. The lowest value was measured at L1, whereas the highest value was measured at $\mathrm{K} 1$ and we think that results from the direct impact of the pollution caused by urban waters and agricultural drainages coming from the city of Kumanova. $\mathrm{Ni}$ trates marked an increasing trend from L1 to K1, followed by a decreasing trend from K1 to P1 and a constant trend from $\mathrm{P} 1$ to $\mathrm{P} 2$ in the end. Low values of nitrates show that river waters are not anthropogenically polluted. The results show that the presence of ammonia, nitrites and nitrates was within the recommended values regarding the river waters of the first/second category. This also comes as a result of the low urban pollution and the reduction of industrial production in the area. 


\section{Chlorides}

Chlorides are less dangerous pollutants in river waters. According to the recommended standards, their presence in river waters is quite high and may reach up to $250 \mathrm{mg} / \mathrm{L}$. In spring, the presence of chlorides in river waters ranged from $2.55-13.0 \mathrm{mg} / \mathrm{L}$. The average seasonal value with standard deviation was $5.67 \pm 3.97 \mathrm{mg} / \mathrm{L}$. The lowest value was measured at L1 and L2, whereas the highest value was measured at $\mathrm{K} 1$. Chlorides marked a mild increasing trend from L1 to L3, followed by an emphasized increasing trend from $\mathrm{L} 3$ to $\mathrm{K} 1$, a decreasing trend from $\mathrm{K} 1$ to $\mathrm{P} 1$ and finally another increasing trend from $\mathrm{P} 1$ to P2. The content of chlorides in the river waters was generally low, indicating minimal anthropogenic pollution.

\section{Metals in sediments}

Metals in general and heavy metals in particular play a crucial role in the pollution of rivers; however, the concentration of some of those metals is beneficial, whereas others are harmful and toxic. The toxicity of heavy metals depends on the type of the metal and the compound, on the amount of metal that reaches the organism and the length of its activity. This group of metals consists of $\mathrm{Hg}, \mathrm{Pb}, \mathrm{Cd}, \mathrm{Cr}, \mathrm{Cu}, \mathrm{Ni}, \mathrm{As}, \mathrm{Zn}$. The process of absorption is responsible for the elimination of metal traces from water in rivers and sediments.

The descriptive statistics of the results obtained from the analysis involving the sediments in respective rivers has been presented in Table 2, whereas the distribution of metals in sediments from the sampling stations has been presented in Figures 2-4. Since the legislation in Macedonia does not cover the issue of metals in sediments, our results were compared to the Dutch standards [Dutch Ministry of Housing, Spatial Planning and Environment, 2015] as well as global average values of sediments in rivers [Emad et al., 2012]. On the basis of the conducted analyses, it was found out that $\mathrm{Fe}$ was present in river sediments in the greatest amounts, followed by other metals such as $\mathrm{Al}, \mathrm{Ca}, \mathrm{Na}, \mathrm{Mg}$. The presence of $\mathrm{Mn}$, $\mathrm{Ba}, \mathrm{Zn}, \mathrm{Sr}, \mathrm{V}, \mathrm{Cr}, \mathrm{Ni}, \mathrm{Pb}, \mathrm{Cu}$, and $\mathrm{Li}$ ranged from 12.6 to $536.8 \mathrm{mg} / \mathrm{kg}$, whereas the presence of $\mathrm{Ag}$, As $(<5 \mathrm{mg} / \mathrm{kg}), \mathrm{Cd}, \mathrm{Co}$, Mo and $\mathrm{Tl}$ was less than $1 \mathrm{mg} / \mathrm{kg}$, i.e. the pollution with these metals was very low. The metals that exceeded the Dutch standard were as follows: $\mathrm{Ba}, \mathrm{Ni}, \mathrm{Zn}, \mathrm{Cr}$ and $\mathrm{Cu}$. The presence of metals in river sediments in the covered area followed this trend: $\mathrm{Fe}>\mathrm{Al}>\mathrm{Ca}>$ $\mathrm{Na}>\mathrm{Mg}>\mathrm{K}>\mathrm{Mn}>\mathrm{Ba}>\mathrm{Sr}>\mathrm{Cr}>\mathrm{Zn}>\mathrm{V}>\mathrm{Ni}$ $>\mathrm{Cu}>\mathrm{Pb}>\mathrm{Li}$.

The concentration of $\mathrm{Al}$ was high and it varied between 28876 and $46495 \mathrm{mg} / \mathrm{kg}$, whereas the average value with standard deviation was $36978.2 \pm 8069.8 \mathrm{mg} / \mathrm{kg}$ and very close to values specific for the winter season. The lowest value was measured in L1, whereas the highest in L3.

The distribution of $\mathrm{Al}$ composition in the concerned stations marked an increasing trend from L1 to L3, a decreasing trend from L3 to P1, and another increasing trend from P1 to P2. The presence of Al is not included in the Dutch standards or in the global average values regarding river sediments.

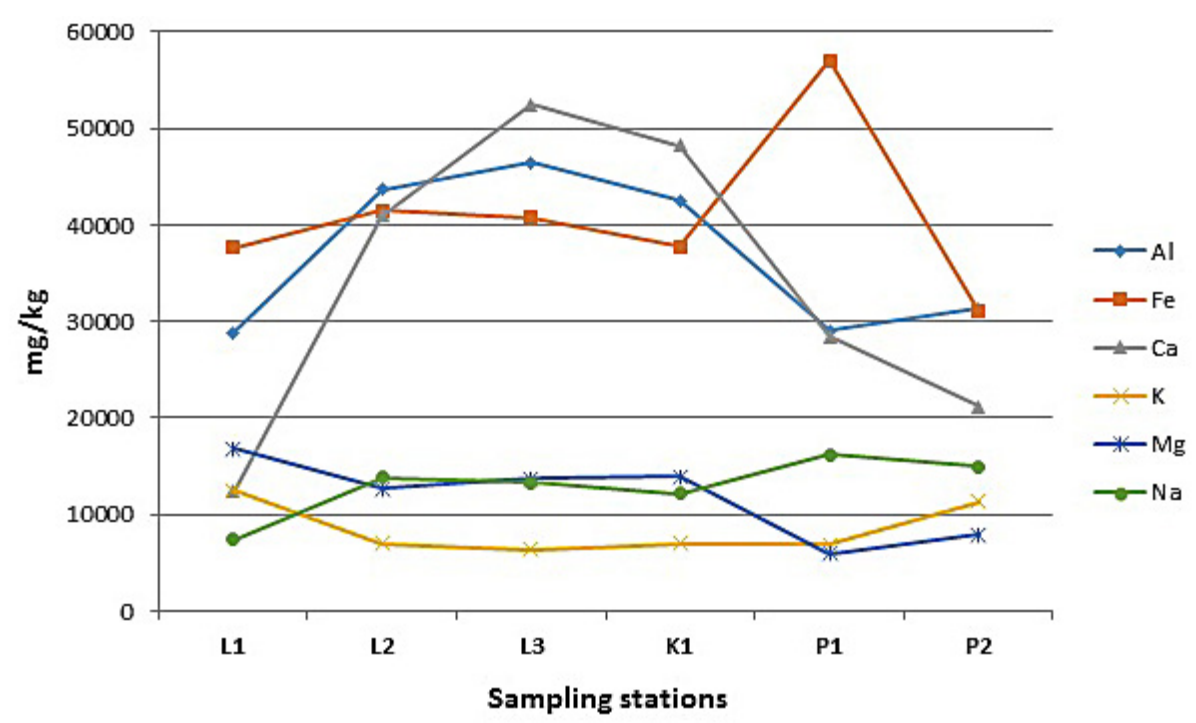

Figure 2. Spatial distribution of $\mathrm{Al}, \mathrm{Fe}, \mathrm{Ca}, \mathrm{K}, \mathrm{Mg}$ and $\mathrm{Na}$ in sediments (mg/kg) 
Table 2. Concentration of metals in the sediments from the Likova, Kumanova and Pçinja rivers $(\mathrm{mg} / \mathrm{kg})$ and descriptive statistics

\begin{tabular}{|c|c|c|c|c|c|c|c|c|c|c|c|}
\hline Stations & $\mathrm{Ag}$ & $\mathrm{Al}$ & $\mathrm{As}$ & $\mathrm{Ba}$ & $\mathrm{Ca}$ & $\mathrm{Cd}$ & $\mathrm{Co}$ & $\mathrm{Cr}$ & $\mathrm{Cu}$ & $\mathrm{Fe}$ & $\mathrm{K}$ \\
\hline $\mathrm{L} 1$ & $<1$ & 28876 & $<5$ & 259 & 12344 & $<1$ & $<1$ & 416 & 40 & 37688 & 12510 \\
\hline $\mathrm{L} 2$ & $<1$ & 43646 & $<5$ & 188 & 40951 & $<1$ & $<1$ & 104 & 35.8 & 41495 & 6981 \\
\hline $\mathrm{L} 3$ & $<1$ & 46495 & $<5$ & 893 & 52402 & $<1$ & $<1$ & 119 & 107 & 40793 & 6323 \\
\hline $\mathrm{K} 1$ & $<1$ & 42472 & $<5$ & 232 & 48181 & $<1$ & $<1$ & 141 & 65.8 & 37776 & 6945 \\
\hline $\mathrm{P} 1$ & $<1$ & 29051 & $<5$ & 1241 & 28444 & $<1$ & $<1$ & 49.9 & 58 & 57020 & 6889 \\
\hline $\mathrm{P} 2$ & $<1$ & 31329 & 29.9 & 408 & 21184 & $<1$ & $<1$ & 50.1 & 142 & 31064 & 11358 \\
\hline Minimum & $/$ & 28876 & $/$ & 188.0 & 12344 & $/$ & $/$ & 49.9 & 35.8 & 31064 & 6323 \\
\hline Maximum & $/$ & 46495 & $/$ & 1241.0 & 52402 & $/$ & $/$ & 416.0 & 142.0 & 57020 & 12510 \\
\hline Median & $/$ & 36901 & $/$ & 333.5 & 34698 & $/$ & $/$ & 111.5 & 61.9 & 39285 & 6963.0 \\
\hline Average & $/$ & 36978.2 & $/$ & 536.8 & 33918 & $/$ & $/$ & 146.7 & 74.8 & 40973 & 8501.0 \\
\hline Stand. Dev. & $/$ & 8069.8 & $/$ & 431.5 & 15824.7 & $/$ & $/$ & 137.0 & 41.6 & 8683.4 & 2694.7 \\
\hline
\end{tabular}

Table 3. Concentration of metals in the sediments from the Likova, Kumanova and Pçinja rivers $(\mathrm{mg} / \mathrm{kg})$ and descriptive statistics

\begin{tabular}{|c|c|c|c|c|c|c|c|c|c|c|c|}
\hline Stations & $\mathrm{Li}$ & $\mathrm{Mg}$ & $\mathrm{Mn}$ & $\mathrm{Mo}$ & $\mathrm{Na}$ & $\mathrm{Ni}$ & $\mathrm{Pb}$ & $\mathrm{Sr}$ & $\mathrm{TI}$ & $\mathrm{V}$ & $\mathrm{Zn}$ \\
\hline $\mathrm{L} 1$ & 25.8 & 16825 & 499 & $<1$ & 7390 & 294 & 23.4 & 55 & $<1$ & 113 & 134 \\
\hline $\mathrm{L} 2$ & 11.5 & 12723 & 938 & $<1$ & 13821 & 50.4 & 27.3 & 107 & $<1$ & 148 & 139 \\
\hline $\mathrm{L} 3$ & 9.95 & 13769 & 847 & $<1$ & 13304 & 66 & 10.5 & 148 & $<1$ & 139 & 196 \\
\hline $\mathrm{K} 1$ & 10.4 & 13920 & 657 & $<1$ & 12158 & 68.4 & 22.8 & 140 & $<1$ & 137 & 134 \\
\hline $\mathrm{P} 1$ & 6.98 & 5989 & 1031 & $<1$ & 16250 & 43.8 & 53.2 & 233 & $<1$ & 207 & 128 \\
\hline $\mathrm{P} 2$ & 11 & 7894 & 617 & $<1$ & 14956 & 35.1 & 53.5 & 202 & $<1$ & 106 & 128 \\
\hline Minimum & 6.98 & 5989 & 499 & $/$ & 7390 & 35.1 & 10.5 & 55 & $/$ & 106 & 128 \\
\hline Maximum & 25.8 & 16825 & 1031 & $/$ & 16250 & 294 & 53.5 & 233 & $/$ & 207 & 196 \\
\hline Median & 10.7 & 13246 & 752 & $/$ & 13562.5 & 58.2 & 25.4 & 144 & $/$ & 138 & 134 \\
\hline Average & 12.6 & 11853.3 & 764.8 & $/$ & 12979.8 & 93 & 31.8 & 147.5 & $/$ & 141.7 & 143.2 \\
\hline Stand. Dev. & 6.7 & 4086.1 & 205.8 & $/$ & 3076.8 & 99.3 & 17.6 & 64.1 & $/$ & 35.9 & 26.2 \\
\hline
\end{tabular}

The concentration of $\mathrm{Fe}$ was higher and it varied between 31064 and $57020 \mathrm{mg} / \mathrm{kg}$, whereas the average value with standard deviation was $40973.0 \pm 8683.4 \mathrm{mg} / \mathrm{kg}$ and much higher than in the winter. The lowest value was measured at P2, whereas the highest at P1. The distribution of Fe at L1 - K1 stations marked an almost constant trend, whereas it changed to an increasing trend at $\mathrm{P} 1$ and then gradually decreasing up to $\mathrm{P} 2$. The content of $\mathrm{Fe}$ is not included in the Dutch standards or in the global average value regarding river sediments $(57405.9 \mathrm{mg} / \mathrm{kg})$.

The concentration of $\mathrm{Ca}$ ranged from 12344 to $52402 \mathrm{mg} / \mathrm{kg}$. The average value with standard deviation was $33918.0 \pm 15824.7 \mathrm{mg} / \mathrm{kg}$ and was much higher than in the winter. The lowest value was measured at L1, whereas the highest was measured at L3. The distribution of the Ca content in the stations under study had an increasing trend from L1 to L3 and a decreasing trend up to $\mathrm{P} 2$. The content of $\mathrm{Ca}$ is not included in the Dutch standards or in the global average values regarding river sediments.
The concentration of $\mathrm{Na}$ ranged from 7390 to $16250 \mathrm{mg} / \mathrm{kg}$. The average value with standard deviation was $12979.8 \pm 3076.8 \mathrm{mg} / \mathrm{kg}$ and was slightly higher than in the winter. The lowest value was measured at L1, whereas the highest was measured at P1. The distribution of the Na content in the stations under study had an increasing trend apart from values at L3 and K1. The content of $\mathrm{Na}$ is not included in the Dutch standards or in the global average values regarding river sediments.

The concentration of $\mathrm{K}$ ranged from 6323 to $12510 \mathrm{mg} / \mathrm{kg}$. The average value with standard deviation was $8501.0 \pm 2694.7 \mathrm{mg} / \mathrm{kg}$ and was lower than in the winter. The lowest value was measured at L3, whereas the highest was measured at L1. The distribution of the K content in the stations under study had a decreasing trend from L1 to L2, whereas it had a somewhat constant trend up to P1 and then an increasing trend from $\mathrm{P} 1$ to $\mathrm{P} 2$. The content of $\mathrm{K}$ is not included in the Dutch standards or in the global average values regarding river sediments. 
The concentration of $\mathrm{Mg}$ ranged from 5989 to $16825 \mathrm{mg} / \mathrm{kg}$. The average value with standard deviation was $11853.3 \pm 4086.1 \mathrm{mg} / \mathrm{kg}$ and was much higher than in the winter. The lowest value was measured at $\mathrm{P} 1$, whereas the highest was measured at $\mathrm{L} 1$. The distribution of the $\mathrm{Mg}$ content in the stations under study had a decreasing trend from L1 to P2, apart from the values at $\mathrm{K} 1$ and P2, where a slight increase was detected. The content of Mg is not included in the Dutch standards or in the global average values regarding river sediments.

The concentration of Mn ranged from 499 to $1031 \mathrm{mg} / \mathrm{kg}$. The average value with standard deviation was $764.8 \pm 205.8 \mathrm{mg} / \mathrm{kg}$ and was much higher than in the winter. The lowest value was measured at L1, whereas the highest was measured at P1. The distribution of the Mn content in the stations under study had an increasingdecreasing-increasing-decreasing trend. The content of $\mathrm{Mn}$ is not included in the Dutch standards or in the global average value regarding river sediments $(975.3 \mathrm{mg} / \mathrm{kg})$.

The concentration of $\mathrm{Ba}$ ranged from 188.0 to $1241 \mathrm{mg} / \mathrm{kg}$. The average value with standard deviation was $536.8 \pm 431.5 \mathrm{mg} / \mathrm{kg}$ and was much higher than in the winter. The lowest value was measured at L2, whereas the highest was measured at P1. The distribution of the Ba content in the stations under study had a repetitive increasing-decreasing trend. The content of $\mathrm{Ba}$ was above the allowed Dutch standards (200 mg/kg), but it is not included in the global average values regarding river sediments.

The concentration of $\mathrm{Zn}$ ranged from 128.0 to $196 \mathrm{mg} / \mathrm{kg}$. The average value with standard deviation was $143.2 \pm 26.2 \mathrm{mg} / \mathrm{kg}$ and was higher than in the winter. The lowest value was measured at $\mathrm{P} 1$ and $\mathrm{P} 2$, whereas the highest was measured at L3. The distribution of the $\mathrm{Zn}$ content in the stations under study had an almost constant trend (apart from the highest value at L3). The content of $\mathrm{Zn}$ was above the allowed Dutch standard (140 $\mathrm{mg} / \mathrm{kg}$ ), but lower than the global average value regarding river sediments $(303 \mathrm{mg} / \mathrm{kg}$ ).

The concentration of $\mathrm{Sr}$ ranged from 55.0 to $233 \mathrm{mg} / \mathrm{kg}$. The average value with standard deviation was $147.5 \pm 64.1 \mathrm{mg} / \mathrm{kg}$ and was much higher than in the winter. The lowest value was measured at L1, whereas the highest was measured at P1. The distribution of the $\mathrm{Zn}$ content in the stations under study had an emphasized increasing trend (apart from values at K1 and P2). The content of $\mathrm{Zn}$ is not included in the Dutch standards or the global average values regarding river sediments.

The concentration of $\mathrm{V}$ ranged from 106.0 to $207 \mathrm{mg} / \mathrm{kg}$. The average value with standard deviation was $141.7 \pm 35.9 \mathrm{mg} / \mathrm{kg}$ and was much higher than in the winter. The lowest value was measured at P2, whereas the highest was measured at P1. The distribution of the V content in the stations under study underwent little changes at L1-K, whereas it was more evident at P1 and $\mathrm{P} 2$. The content of $\mathrm{V}$ is not included in the Dutch standards or the global average values regarding river sediments.

The concentration of $\mathrm{Cr}$ ranged from 49.9 to $416 \mathrm{mg} / \mathrm{kg}$. The average value with standard deviation was $146.7 \pm 137.0 \mathrm{mg} / \mathrm{kg}$ and was much higher than in the winter. The lowest value was measured at P1, whereas the highest was mea-

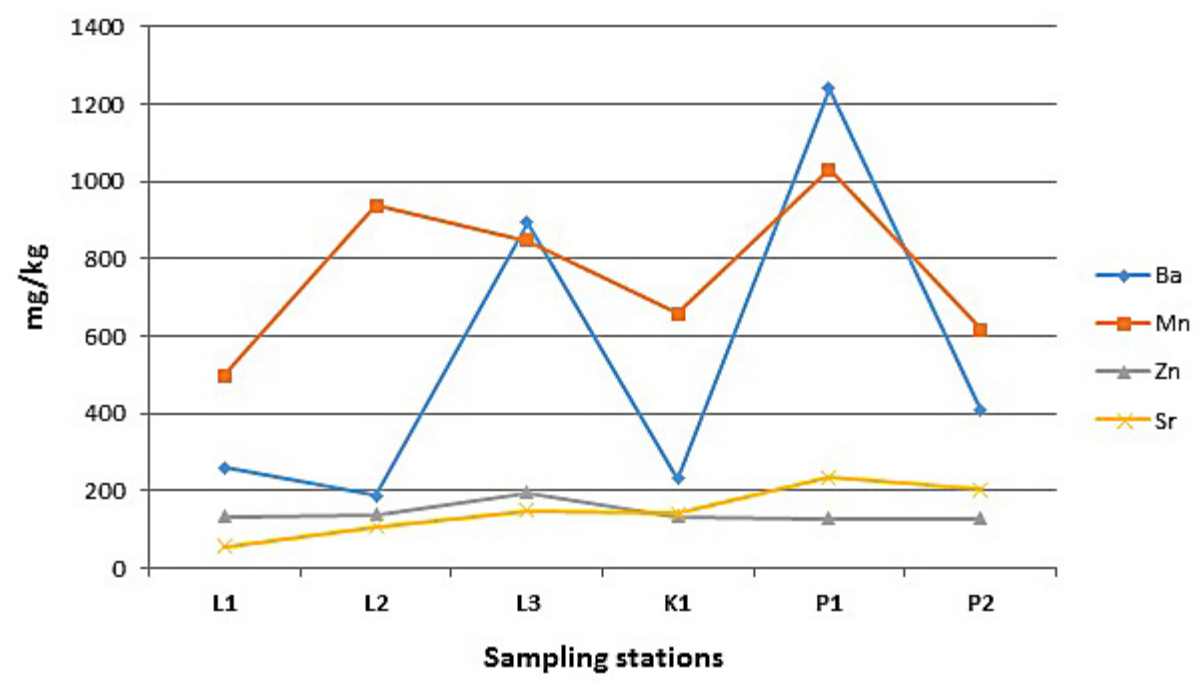

Figure 3. Spatial distribution of $\mathrm{Ba}, \mathrm{Mn}, \mathrm{Zn}$ and $\mathrm{Sr}$ in sediments $(\mathrm{mg} / \mathrm{kg}$ ) 
sured at L1. The higher concentration of $\mathrm{Cr}$ at L1 is most probably due to the mineralogical composition of the basin of the Likova River. The distribution of the $\mathrm{Cr}$ content in the stations under study had a decreasing trend from L1 to L2, a mild increasing trend from $\mathrm{L} 2$ to $\mathrm{K} 1$ and a decreasing trend from $\mathrm{K} 1$ to $\mathrm{P} 2$. The content of $\mathrm{Cr}$ was above the allowed Dutch standard $(100 \mathrm{mg} / \mathrm{kg})$, as well as higher than the global average value regarding river sediments $(126 \mathrm{mg} / \mathrm{kg})$.

The concentration of $\mathrm{Ni}$ ranged from 35.1 to $294 \mathrm{mg} / \mathrm{kg}$. The average value with standard deviation was $93.0 \pm 99.3 \mathrm{mg} / \mathrm{kg}$ and was much higher than in the winter. The lowest value was measured at P2, whereas the highest was measured at L1. The distribution of the Ni content in stations under study had a drastically decreasing trend from L1 to L2, and then an almost constant trend from L2 to P2. The content of Ni was above the allowed Dutch standard ( $35 \mathrm{mg} / \mathrm{kg}$ ), but lower than the global average value regarding river sediments $(102.3 \mathrm{mg} / \mathrm{kg})$.

The concentration of $\mathrm{Pb}$ ranged from 10.5 to $53.3 \mathrm{mg} / \mathrm{kg}$. The average value with standard deviation was $31.8 \pm 17.6 \mathrm{mg} / \mathrm{kg}$ and was lower than in the winter. The lowest value was measured at L3, whereas the highest was measured at P2. The distribution of the $\mathrm{Pb}$ content in the stations under study had an increasing trend from L1 to L2, a decreasing trend from L2 to L3 and another increasing trend from L3 to P2. We believe that this increase in the concentration of $\mathrm{Pb}$ in sediments is because of greater urban pollution in the city of Kumanova. The content of $\mathrm{Pb}$ was below the allowed Dutch standard $(85 \mathrm{mg} / \mathrm{kg})$, as well as lower than the global average value regarding river sediments $(230.75 \mathrm{mg} / \mathrm{kg})$.
The concentration of $\mathrm{Cu}$ ranged from 35.8 to $142.0 \mathrm{mg} / \mathrm{kg}$. The average value with standard deviation was $74.8 \pm 41.6 \mathrm{mg} / \mathrm{kg}$ and was higher than in the winter. The lowest value was measured at L2, whereas the highest was measured at P2. The distribution of the $\mathrm{Cu}$ content in the stations under study had a generally increasing trend from L1 to P2 (apart from values at K1 and $\mathrm{P} 1)$. The content of $\mathrm{Cu}$ in sediments was above the allowed Dutch standard ( $36 \mathrm{mg} / \mathrm{kg}$ ), but lower than the global average value regarding river sediments $(122.9 \mathrm{mg} / \mathrm{kg})$.

The concentration of Li ranged from 6.98 to $25.8 \mathrm{mg} / \mathrm{kg}$. The average value with standard deviation was $12.6 \pm 6.7 \mathrm{mg} / \mathrm{kg}$ and almost identical with that in the winter. The lowest value was measured at P1, whereas the highest was measured at L1. The distribution of the Li content in stations under study had a drastically decreasing trend from L1 to L2, then a slightly decreasing trend from L2 to P1 and then an increasing trend from $\mathrm{P} 1$ to $\mathrm{P} 2$. The content of $\mathrm{Cu}$ in the sediments was above the allowed Dutch standard $(36 \mathrm{mg} / \mathrm{kg}$ ), but lower than the global average value regarding river sediments $(122.9 \mathrm{mg} / \mathrm{kg})$. The content of $\mathrm{Li}$ is not included in the Dutch standards or the global average values regarding river sediments.

\section{Correlation coefficients of the concentration of metals in sediments of the rivers Likova, Kumanova and Pçinja}

After determining the concentrations of metals in the sediments of the rivers Likova, Kumanova and Pçinja, the obtained results were analyzed statistically. This analysis helped to determine the correlation among the parameters (concentrations

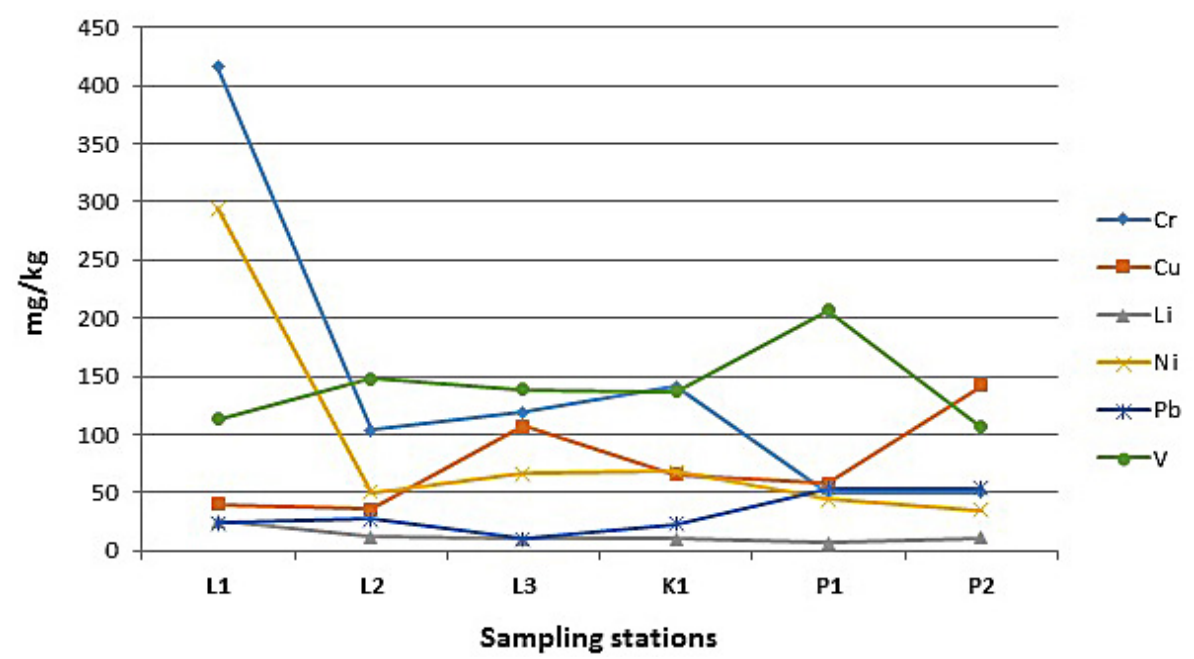

Figure 4. Spatial distribution of $\mathrm{Cr}, \mathrm{Cu}, \mathrm{Li}, \mathrm{Ni}, \mathrm{Pb}$ and $\mathrm{V}$ in sediments $(\mathrm{mg} / \mathrm{kg})$ 
of metals in sediments at the sampling stations) by using the Carl Pearson correlation coefficient ( $r$ ) between two variables (parameters). The correlation coefficient shows that the level of correlation existing between two given parameters. The greater the coefficient value, the better the correlation between parameters. If the value of the correlation coefficient $(r)$ between two parameters is large, this means that these variables are closely connected to one another. The value of $r$ can range between 0 and 1 and 0 to -1 . When the value of $r$ gets closer to 1 , there is an emphasized positive correlation between the parameters, i.e. with the increase of the value of one of the parameters, the value of the other parameter increases as well. On the other hand, when the value of $r$ gets closer to -1 , the correlation between parameters is negative, i.e. when one of them increases the other decreases.

The correlation coefficients of the concentration of sediments in the rivers of Likova, $\mathrm{Ku}-$ manova and Pçinja have been shown in Table 4. Al revealed high positive correlation with $\mathrm{Ca}(r=$ $0.926)$, whereas an emphasized negative correlation was noticed between $\mathrm{Al}$ and $\mathrm{Pb}(r=-0.712)$. $\mathrm{Ba}$ was in a strong positive correlation with $\mathrm{Fe}$ and $\operatorname{Sr}(r=0.759$ and $r=0.691)$, whereas in a moderate negative correlation with $\mathrm{K}(r=-0.878) . \mathrm{Cr}$ revealed high positive correlation with $\mathrm{Ni}(r=$ $0.998)$, and high negative correlation with $\mathrm{Na}(r$ $=-0.974)$. Cu revealed moderate positive correlation with $\mathrm{Sr}(r=0.533)$, and moderate negative correlation with $\mathrm{Fe}(r=-0.453)$. Fe revealed high positive correlation with $\mathrm{V}(r=0.973)$, and moderate negative correlation with $\mathrm{Mn}(r=-0.790)$. Li revealed high positive correlation with $\mathrm{Ni}(r$ $=0.967)$ and high negative correlation with $\mathrm{Na}$ $(r=-0.931)$. Mg showed an emphasized positive correlation with $\mathrm{Cr}(r=0.781)$, and high negative correlation with $\mathrm{Sr}(r=-0.937)$. Mn showed an emphasized positive correlation with $\mathrm{V}(r=$ 0.858 ), and moderate negative correlation with $\mathrm{Ni}(r=-0.635)$. Na was characterized with an emphasized positive correlation with $\mathrm{Sr}(r=$ $0.889)$, and high negative correlation with $\mathrm{Ni}(r=$ $-0.931)$. Ni was characterized with a high positive correlation with $\mathrm{Cr}(r=0.988)$ and $\mathrm{Li}(r=0.967)$, and an emphasized negative correlation with $\mathrm{Na}$ $(r=-0.931) . \mathrm{Pb}$ revealed emphasized positive correlation with $\mathrm{Sr}(r=0.713)$, and high negative correlation with $\mathrm{Mg}(r=-0.879)$. Sr showed high positive correlation with $\mathrm{Na}(r=0.889)$ and $\mathrm{Pb}(r=0.713)$, and very high negative correlation with $\mathrm{Mg}(r=-0.937)$ and an emphasized negative correlation with Ni $(r=-0.756)$. V was characterized by a very high positive correlation with $\mathrm{Fe}(r=0.973)$, and a moderate negative correlation with $\mathrm{Mg}(r=-0.537)$. $\mathrm{Zn}$ was characterized by a moderate positive correlation with $\mathrm{Al}(r=$ $0.666)$, and a moderate negative correlation with $\mathrm{Pb}(r=-0.693)$.

The rivers Likova, Kumanova and Pçinja are the most important rivers in the region of Kumanova. They have mainly carbonate basins, which give bicarbonate characteristics to their water. Few studies on the waters and sediments

Table 4. Correlation coefficients of the concentration of metals in sediments of the rivers Likova, Kumanova and Pçinja

\begin{tabular}{|c|c|c|c|c|c|c|c|c|c|c|c|c|c|c|c|c|}
\hline Correlations & $\mathrm{Al}$ & $\mathrm{Ba}$ & $\mathrm{Ca}$ & $\mathrm{Cr}$ & $\mathrm{Cu}$ & $\mathrm{Fe}$ & K & $\mathrm{Li}$ & $\mathrm{Mg}$ & $\mathrm{Mn}$ & $\mathrm{Na}$ & $\mathrm{Ni}$ & $\mathrm{Pb}$ & $\mathrm{Sr}$ & V & $\mathrm{Zn}$ \\
\hline $\mathrm{Al}$ & 1.000 & & & & & & & & & & & & & & & \\
\hline $\mathrm{Ba}$ & -0.185 & 1.000 & & & & & & & & & & & & & & \\
\hline $\mathrm{Ca}$ & 0.926 & 0.104 & 1.000 & & & & & & & & & & & & & \\
\hline $\mathrm{Cr}$ & -0.262 & -0.419 & -0.456 & 1.000 & & & & & & & & & & & & \\
\hline $\mathrm{Cu}$ & 0.019 & 0.189 & 0.055 & -0.471 & 1.000 & & & & & & & & & & & \\
\hline $\mathrm{Fe}$ & -0.172 & 0.759 & 0.093 & -0.249 & -0.453 & 1.000 & & & & & & & & & & \\
\hline K & -0.692 & -0.411 & -0.878 & 0.593 & 0.148 & -0.537 & 1.000 & & & & & & & & & \\
\hline $\mathrm{Li}$ & -0.365 & -0.509 & -0.611 & 0.962 & -0.358 & -0.383 & 0.761 & 1.000 & & & & & & & & \\
\hline $\mathrm{Mg}$ & 0.388 & -0.596 & 0.143 & 0.781 & -0.390 & -0.438 & 0.170 & 0.694 & 1.000 & & & & & & & \\
\hline $\mathrm{Mn}$ & 0.268 & 0.635 & 0.452 & -0.654 & -0.194 & 0.787 & -0.790 & -0.721 & -0.526 & 1.000 & & & & & & \\
\hline $\mathrm{Na}$ & 0.100 & 0.553 & 0.319 & -0.974 & 0.402 & 0.406 & -0.549 & -0.931 & -0.877 & 0.734 & 1.000 & & & & & \\
\hline $\mathrm{Ni}$ & -0.396 & -0.328 & -0.570 & 0.988 & -0.438 & -0.189 & 0.659 & 0.967 & 0.679 & -0.635 & -0.931 & 1.000 & & & & \\
\hline $\mathrm{Pb}$ & -0.712 & 0.298 & -0.549 & -0.463 & 0.262 & 0.243 & 0.257 & -0.315 & -0.879 & 0.174 & 0.577 & -0.344 & 1.000 & & & \\
\hline $\mathrm{Sr}$ & -0.210 & 0.691 & 0.089 & -0.836 & 0.533 & 0.409 & -0.325 & -0.811 & -0.937 & 0.502 & 0.889 & -0.756 & 0.713 & 1.000 & & \\
\hline V & -0.064 & 0.734 & 0.227 & -0.438 & -0.374 & 0.973 & -0.660 & -0.568 & -0.537 & 0.858 & 0.565 & -0.393 & 0.296 & 0.528 & 1.000 & \\
\hline $\mathrm{Zn}$ & 0.666 & 0.299 & 0.622 & -0.043 & 0.275 & -0.040 & -0.425 & -0.145 & 0.340 & 0.195 & -0.018 & -0.095 & -0.693 & -0.120 & -0.066 & 1.000 \\
\hline
\end{tabular}


in these rivers have been carried out (Popova et al., 2015). The urban wastewater treatment plant, which cleans the water from the pollutants thus contributing to the preservation of the water in the rivers of Kumanova and Pçinja, is situated just outside the city of Kumanova. On the basis of the physicochemical parameters, it resulted in low levels of pollution of these waters, meaning that they belong to the first/second class.

In general, the pollution of rivers with metals has varied at different monitoring stations; the content of some metals was higher at the upper flows, whereas others were reduced at lower flows of the rivers in question. The pollution in river basins is caused by the rinsing of soil from the water in rivers, by the regional erosion from rainfalls, by black waters flowing from residential areas that accumulate more at river basins, by outflowing waters from the few factories in the city (even though they operate at reduced capacity) as well as by the general pollution of the environment in the region of the municipality of Kumanova. Industrial, agricultural and household pollutants are deposited in rivers, which has caused some pollution to occur. On the basis of the obtained results, we concluded that this mild pollution in rivers was caused by urban, agricultural and industrial activities.

\section{CONCLUSIONS}

In order to explore the pollution level of sediments with metals, twenty two metals were analyzed in sediment samples taken from six sampling stations in the rivers of Likova, Kumanova and Pçinja. The sustainability of metals in the river sediments in the examined area in the spring season conformed to the following order: $\mathrm{Fe}>\mathrm{Al}$ $>\mathrm{Ca}>\mathrm{Na}>\mathrm{Mg}>\mathrm{K}>\mathrm{Mn}>\mathrm{Ba}>\mathrm{Sr}>\mathrm{Cr}>\mathrm{Zn}$ $>\mathrm{V}>\mathrm{Ni}>\mathrm{Cu}>\mathrm{Pb}>$ Li. International sediment quality assurance guidelines were used in assessing the pollution levels. According to them, the analyzed sediments were mostly polluted by $\mathrm{Fe}$, $\mathrm{Al}, \mathrm{Ca}, \mathrm{Na}, \mathrm{Mg}, \mathrm{K}$ and $\mathrm{Mn}$. Average presence was detected for $\mathrm{Ba}, \mathrm{Zn}, \mathrm{Sr}, \mathrm{V}, \mathrm{Cr}, \mathrm{Ni}, \mathrm{Pb}, \mathrm{Cu}$ and $\mathrm{Li}$, whereas the presence of $\mathrm{Ag}, \mathrm{Cd}, \mathrm{Co}, \mathrm{Mo}, \mathrm{Tl}$ and As was very low $(<1 \mathrm{mg} / \mathrm{kg})$. The metals that exceeded the Dutch standard on sediments were the following: $\mathrm{Ba}, \mathrm{Ni}, \mathrm{Zn}, \mathrm{Cr}$ and $\mathrm{Cu}$. The distribution of metals in the sediments showed very low presence of anthropogenic elements $(\mathrm{Cu}, \mathrm{Cr}$, $\mathrm{Mn}, \mathrm{Ni}, \mathrm{Pb}, \mathrm{V}$ and $\mathrm{Zn}$ ) podischarged by the indus- try, agricultural activities and households. On the basis of the physico-chemical quality assessment of the water from these rivers, we conclude that it belongs to the first/second category, as determined by the state regulations, and in general, it was polluted to a very small degree.

\section{REFERENCES}

1. APHA, AWWA, WEF. 1995. Standard methods for the examination of water and wastewater, 19th ed. Washington, DC: American Public Health Association/America Water Works Association/Water environment federation.

2. Bekteshi A. 2014. Heavy Metals in the Shkodra Lake Ecosystem. Journal of Environmental Protection and Ecology, 15(3), 834-841.

3. Dossis P. and Warren L.J. 1980. Distribution of heavy metals between the minerals and organic debris in a contaminated marine sediment. Ann Arbor Sci., Ann Arbor, MI, 119-127.

4. Durmishi B.H. 2013. The study of the trihalomethanes (THMs) content variation with advanced analytical methods in the drinking water in the city of Tetova. Ph.D. Thesis, University of Tirana, Albania.

5. Dutch Ministry of Housing, Spatial Planning and Environment: Available at http://www.contaminatedland.co.uk/std-guid/dutch-l. htm (Accessed sep 2015)

6. Salah E.A.M., Zaidan T.A., Al-Rawi A.S. 2012. Assessment of heavy metals pollution in the sediments of Euphrates river, Iraq. Journal of Water Resource and Protection, Vol. 4, 1009-1023.

7. Gehan M.E.G.E.K. 2012. Studies of Some Heavy Metals in Water and Sediment in El-Max Fish Farm, Egypt. World Applied Sciences Journal,18(2), 171-180.

8. Jain C.K. 2004. Metal fractionation study on bed sediments of River Yamuna, India, Water Research 38, 569-578.

9. Lewis D.W. and McConchie D.M. 1994. Analytical Sedimentology. Chapman and Hall. New York, USA.

10. Malik N.B.A. 2010. Bioaccumulation of heavy metals in fish tissues of a freshwater lake of Bhopal. Environ. Monit. Assess, 160, 267-267.

11. Mandalia C.P. 2011. Impact of Environmental Pollution on Human Future. World Journal of Environmental Pollution, 1(2), 8-10.

12. Mehdi Hosseini A.A. 2012. Concentrations of Heavy Metals in Selected Tissues of Blue Swimming Crab, Portunus pelagicus (Linnaeus, 1758) and Sediments from Persian Gulf. World Applied Sciences Journal, 19(10), 1398-1405. 
13. Mollazadeh N.F.M. 2013. Distribution of Metals, Chemical Partitioning, Pollution and Origins in Riverbed Sediment. World Applied Sciences Journal, 21 (5), 674-680.

14. Oetken M.E. 2005. Impact of flood disaster on sediment toxicity in a major river system -the Elbe flood 2002 as a case study. Environmental Pollution, 134, 87.

15. Rahimi S.M. 2012. Determination of Lead Residue in Raw Cow Milk from Different Regions of Iran by Flameless Atomic Absorption Spectrometry. American-Eurasian Journal of Toxicological Sciences, 4(1), 16-19.
16. Sakan D.S, Dordevic D.S, Manojlovic D.D, Predrag P.S. 2009. Assessment of heavy metal pollutants accumulation in the Tisza river sediments. J. Environ. Manage., 90, 3382.

17. Shanur Jahedul Hasan M.B. 2015. Physico-chemical characteristics and accumulation of heavy metals in water and sediments of the river Dakatia, Bangladesh. International Journal of Fisheries and Aquatic Studies, 300-304.

18. Popova S.I., Stafilov T., Šajnc R. and Tanaselia C. 2015. Distribution of trace elements in sediment and soil from river Vardar basin, Macedonia/ Greece. Journal of Environmental Science and Health, Part A, 1-14. 